\title{
Human Autoantibodies and Monoclonal Antibody KHRI-3 Bind to a Phylogenetically Conserved Inner-ear-supporting Cell Antigen ${ }^{a}$
}

\author{
MICHAEL J. DISHER, ${ }^{c}$ ANNA RAMAKRISHNAN, THANKAM S. NAIR, \\ JOSEF M. MILLER, STEVEN A. TELIAN, H. ALEXANDER ARTS, \\ ROBERT T. SATALOFF ${ }^{d}$ RICHARD A. ALTSCHULER, \\ YEHOASH RAPHAEL, THOMAS E. CAREY ${ }^{b}$ \\ Department of Otolaryngology/Head and Neck Surgery \\ The University of Michigan \\ Kresge Hearing Research Institute \\ 1301 East Ann Street \\ Ann Arbor, Michigan 48109-0506
}

\section{INTRODUCTION}

Autoimmunity as a cause of sensorineural hearing loss ${ }^{1-3}$ has yet to be completely confirmed or characterized. However, the evidence of antibody to inner-ear antigens in sera from patients with the clinical diagnosis of autoimmune sensorineural hearing loss (AISNHL) and experimental models strongly support this possibility. ${ }^{4-21}$

In 1987, Harris $^{6}$ demonstrated hearing loss and inner-ear lesions in guinea pigs immunized with bovine inner-ear extract. Subsequently, Orosco et al. ${ }^{8}$ immunized mice and guinea pigs with chick and guinea pig inner-ear tissues and found that the animals developed transient hearing loss and serum antibodies to hair cell stereocilia. We followed these experiments with the development of monoclonal antibodies to inner-ear antigens by immunizing mice with chick and guinea pig inner-ear tissue. ${ }^{22,23}$ We characterized two classes of monoclonal antibodies (MAb) to inner-ear antigens. One class (KHRI-5 and KHRI-6) stains stereocilia. ${ }^{23}$ The other class is represented by MAb KHRI-3, which binds to inner ear supporting cells in a characteristic punctate "stacked wine glass" staining pattern. ${ }^{22}$ It also identifies a $68-\mathrm{kD}$ protein in Western blots of inner-ear extracts. ${ }^{20}$

In vivo studies showed that mice carrying the KHRI-3 hybridoma develop highfrequency hearing loss. ${ }^{20}$ The hearing loss is associated with high circulating KHRI3 antibody titers and loss of outer hair cells in the basal turn of the cochlea, the region that encodes high-frequency sounds. More recent studies using in vivo infusion

${ }^{a}$ This work was supported by the Lynn and Ruth Townsend Fund, Deafness Research Foundation, NIH P01-DC00078-27, NIH NIDCD R01-DC02272.

${ }^{b}$ Address for correspondence: Thomas E. Carey, Ph.D., Cell Biology and Immunology Lab, 6020 KHRI, 1301 East Ann Street, Ann Arbor, MI 48109-0506. Phone: 313/764-4371; fax 313/764-0014; e-mail: careyte@umich.edu 46802 .

'Present address: Ear, Nose and Throat Associates, 347 West Berry Street, Fort Wayne, IN

'Present address: 1721 Pine Street, Philadelphia, PA 19103. 
of KHRI-3 antibody directly into the guinea pig cochlea have shown that KHRI-3 binds to supporting cells in vivo, and that animals receiving this antibody, but not an isotype-matched IgG1 myeloma protein, develop hearing loss. ${ }^{24}$ These experimental studies provide strong evidence for antibody-mediated disruption of hearing.

Support for antibody-mediated hearing loss in humans also has accumulated. Harris and his colleagues demonstrated that serum antibodies from patients with AISNHL bind to a $68-\mathrm{kD}$ protein in bovine inner-ear tissue extracts. ${ }^{7,16-18}$ In a recent report, the cumulative data were summarized. ${ }^{16}$ Of 279 patients with rapidly progressive sensorineural hearing loss, $32 \%$ were positive for the $68-\mathrm{kD}$ antigen on Western blots. ${ }^{16}$ Hughes et al. ${ }^{25}$ reported finding antibodies to a $68-\mathrm{kD}$ antigen in $86 \%$ of patients with what they termed idiopathic, progressive, bilateral sensorineural hearing loss (IPBSNHL), whereas Moscicki et al. ${ }^{18}$ found this type of antibody activity in 42 of $72(58 \%)$ patients. These groups also found that the presence of antibody predicted a clinical response to treatment with steroids.

The reactivity of human autoantibodies with heterologous tissues is based on the assumption that the autoantibodies bind to phylogenetically conserved proteins in the inner ear. Thus, human autoantibodies to inner ear have been detected using bovine inner-ear substrates. ${ }^{7}, 15-18,25$ In support of this concept, Harris and Sharp ${ }^{7}$ showed similar antibody binding on human, bovine, and guinea pig inner-ear substrates. Cao et al. ${ }^{19,21}$ recently reported the use of guinea pig inner-ear extracts as a substrate for detecting autoantibodies from patients with AISNHL. This group found antibodies to proteins of 58 and $30 \mathrm{kD}$ on Western blots, which differs from the more common finding of a $68-\mathrm{kD}$ protein.

In the present study, we used guinea pig inner-ear tissue as the substrate for detection of inner-ear reactive antibodies in sera from patients with AISNHL. We show that roughly one-half of patients clinically assessed as having possible AISNHL have antibodies that bind to a $68-70-\mathrm{kD}$ protein in guinea pig inner-ear extracts. The same sera also stain supporting cells in the organ of Corti with a pattern like that of the KHRI-3 monoclonal antibody. This is the first demonstration that sera from humans with sudden/rapidly progressive hearing loss have a reproducible binding pattern in the inner ear. In addition, we show that a $68-70-\mathrm{kD}$ inner ear protein immunoprecipitated by KHRI-3 is also reactive with human autoantibodies. Furthermore, human inner-ear-tissue, but not blood cells from the same donor, absorbs the reactivity to guinea pig inner-ear substrate, indicating that the antibodies define a phylogenetically conserved protein expressed in human and guinea pig ears.

\section{METHODS}

\section{Serum Samples}

Patients with suspected autoimmune inner-ear disorders evaluated in the Department of Otolaryngology at the University of Michigan and in cooperating private otolaryngology practices in Pennsylvania, Michigan, and Indiana, were asked to participate in the study, which was approved by the University of Michigan Institutional Review Board. Serum samples and histories were obtained from patients giving writ- 
ten informed consent. Sera from 91 patients thought to have autoimmune hearing loss were analyzed, and the records of the patients were subsequently reviewed and categorized. Although the criteria for patients with AISNHL was to include only patients with sudden onset and rapidly progressive or fluctuating hearing loss, not all cases fit this criterion on review. Hearing loss was defined as greater than $30 \mathrm{~dB}$ at any frequency, or less than $85 \%$ speech discrimination in either one (unilateral) or both ears (bilateral). If the hearing loss developed within a $24-\mathrm{h}$ period and did not progress subsequently, the patient was considered to have sudden hearing loss. Either unilateral or bilateral hearing loss with greater than $10-\mathrm{dB}$ progression within three months was classified as rapidly progressive. Seventeen patients that did not fit in these categories were not included in the analysis. KHRI-3 monoclonal antibody batches were prepared from hybridoma supernatant, ascites fluid, or concentrated supernatant from hybridoma cells grown in a bioreactor. ${ }^{20,22,24}$

\section{Western Blotting}

All studies described in this report were approved by the University of Michigan Committee on Use and Care of Animals and NIH NIDCD P01 DC00078 and R01 DC02272. Veterinary care and housing were provided by the Unit for Laboratory Animal Medicine of the University of Michigan. Guinea pig inner-ear extracts were made as described previously. ${ }^{20,22}$ The organ of Corti and vestibular tissues were collected on ice and immediately dissolved in lysis buffer (1\% NP-40 in phosphatebuffered saline $\mathrm{pH} 7.2$ (PBS) containing protease inhibitors, including $1 \mathrm{mM}$ PMSF, leupeptin $1 \mu \mathrm{g} / \mathrm{mL}$, antipain $2 \mu \mathrm{g} / \mathrm{mL}$, benzamidine $10 \mu \mathrm{l} / \mathrm{mL}$, aprotinin $10 \mathrm{ku} / \mathrm{mL}$, chymostatin $1 \mu \mathrm{g} / \mathrm{mL}$, pepstatin $1 \mu \mathrm{g} / \mathrm{mL}$ ), and allowed to stand on ice for $30 \mathrm{~min}$ after homogenizing. The homogenates and the molecular-weight standards were prepared for polyacrylamide gel electrophoresis (PAGE) using sample buffer containing $0.0625 \mathrm{M}$ tris-HCL pH $6.8,2 \% \mathrm{SDS}, 10 \%$ glycerol, and $0.005 \%$ bromophenol blue. For reducing conditions, the sample buffer contained $5 \%(\mathrm{v} / \mathrm{v}) 2$-mercaptoethanol. The samples were boiled for $5 \mathrm{~min}$ and separated on 3\% stacking and $7 \%$ separating gels. ${ }^{26}$ For the $7 \times 8$-cm gels, $30-\mu$ g protein was loaded per lane and $100 \mu \mathrm{g}$ of protein per lane was loaded in the $14 \times 16-\mathrm{cm}$ gel. Standards $(200-14.3 \mathrm{kD})$ were from Amersham (Arlington Heights, Illinois). The gels were run at constant current of 25 $\mathrm{mA} /$ gel for 90 minutes for the minigels and at constant current of $35 \mathrm{~mA} / \mathrm{gel}$ for $4 \mathrm{~h}$ for the larger gels. Electrophoretic transfer to nitrocellulose paper was performed at constant voltage of $35 \mathrm{~V}$ overnight. ${ }^{27}$ The nitrocellulose paper was cut into strips, incubated with milk buffer (Blotto) $(50 \mathrm{mM}$ tris-HCL, pH 8.0, containing 5\% nonfat dry milk, $2 \mathrm{mM} \mathrm{CaCl}$, and $5 \%$ Tween 20 ) to block nonspecific binding. All subsequent incubations were done in this buffer. The strips were incubated for $2 \mathrm{~h}$ at room temperature with human serum diluted at $1: 50$, or KHRI-3 diluted to $10 \mu \mathrm{g} / \mathrm{mL}$, washed three times for $10 \mathrm{~min}$ each, and incubated for $2 \mathrm{~h}$ in secondary antibody (goat antihuman IgG/IgM or antimouse IgG heavy and light chain-specific conjugated to horseradish peroxidase from Jackson ImmunoResearch Laboratories Inc., West Grove, Pennsylvania) diluted at 1:500. The blots were developed with 4-chloro-1naphthol $(0.5 \mathrm{mg} / \mathrm{mL})$ in methanol-PBS, pH $7.6(1: 5)$ containing $0.05 \% \mathrm{H}_{2} \mathrm{O}_{2}$. 


\section{Immunofluorescence}

Guinea pigs were decapitated and the bullas were fixed locally with $4 \%$ paraformaldehyde for $2 \mathrm{~h}$. The cochleae were dissected free of the surrounding bone, the spiral ligament and tectorial membrane were removed, and the central bony cochleae containing the organ of Corti were incubated in 3\% normal goat serum for 1 $h$. The specimens were washed three times for five minutes in PBS, incubated in the primary antibody (serum diluted at 1:50 or KHRI-3 $10 \mu \mathrm{g} / \mathrm{mL}$ ) overnight at $4^{\circ} \mathrm{C}$, washed three times for $5 \mathrm{~min}$ in PBS, and incubated for $45 \mathrm{~min}$ at room temperature in the secondary antibody (Lissamine Rhodamine LRSC anti-Human IgG/IgM heavy and light chain-specific from Jackson ImmunoResearch Laboratories Inc, West Grove, or rhodamine (TRITC) conjugated to goat antimouse anti-IgG, Accurate Chemicals, Old Westbury, New York), diluted 1:200 in PBS (pH 7.4). The cochleae were washed in PBS, and then the organ of Corti was carefully peeled off the modiolus and mounted in GVA mounting media (Zymed Labs, San Francisco, California).

\section{Immunoprecipitation and Western Blotting}

The KHRI-3 antigen was immunoprecipitated from guinea pig cochlea and vestibular tissue extracts using KHRI-3 antibody. For each lane in an experiment, cochlear and vestibular tissue from both ears of a guinea pig were homogenized in $25-\mu \mathrm{L}$ lysis buffer with protease inhibitors as described earlier. The lysate $(25-\mu \mathrm{L})$ was mixed with $50 \mu \mathrm{L}$ of BSA and $150 \mu \mathrm{L}$ of wash buffer containing $1 \%$ Nonidet P$40,50 \mathrm{mM}$ tris- $\mathrm{Cl}(\mathrm{pH} 8), 150 \mathrm{mM} \mathrm{NaCl}, 0.1 \%$ sodium deoxycholate, $0.1 \%$ SDS, and $1 \mathrm{mM}$ phenylmethylsulfonyl fluoride per sample. The samples were precleared twice with protein G-agarose for 30 minutes and incubated overnight at $4^{\circ} \mathrm{C}$ with 200 $\mu \mathrm{L}$ of the KHRI-3 antibody from hybridoma supernatant. Antibody-antigen complexes were precipitated by incubation with protein G-agarose for 2 hours at $4^{\circ} \mathrm{C}$. The supernatant was removed after centrifugation at $5000 \times \mathrm{g}$ for $5 \mathrm{~min}$. The precipitates were washed four times with wash buffer, centrifuged, resuspended in running buffer under reducing or nonreducing conditions, and separated by SDS-PAGE using a $7 \%$ gel. ${ }^{22,23}$ The gel was electrophoresed at $25 \mathrm{~mA}$ of constant current. The proteins were transferred as described earlier and Western blotted with human sera or KHRI-3 antibody as described before.

\section{Absorption}

Two absorptions of human sera containing antibody reactive with the guinea pig inner ear were performed using part of the cochlea and labyrinth of two acoustic neuroma patients who were undergoing ablative surgery. The tissue was saved and transported to the lab together with an anticoagulated sample of each patient's whole blood. The patients gave prior written consent to use these tissues. The blood was centrifuged at $700 \times \mathrm{g}$ to pellet the buffy coat and red cells. The buffy coat was carefully removed and washed once in PBS. An aliquot of the red cell layer was also removed and washed in PBS. The inner-ear tissue was put into a microcentrifuge tube 
and washed once with PBS. The volume of the inner-ear tissue was estimated, and an equal volume of packed white cells and packed red cells were placed in similar tubes. Each sample was mixed with an equal volume of serum (diluted 1:50 in PBS) from an antibody-positive patient, UM-HL-37, incubated overnight at $4{ }^{\circ} \mathrm{C}$, then warmed to room temperature for $30 \mathrm{~min}$. One aliquot of the same serum dilution was incubated identically without any absorbing tissue as a positive control. The tubes were centrifuged for $4 \mathrm{~min}$, the sera was carefully pipetted out, and the absorbed and sham absorbed samples were incubated with segments of surface preparations of guinea pig organ of Corti prepared as described earlier for immunofluorescence staining. After three washes in PBS, the cochleae were incubated with lissamine rhodamine goat antihuman IgG/IgM from Jackson Immunochemicals at 1:200 for $1 \mathrm{~h}$ at room temperature. After four 5-min washes in PBS, the surface preparations were mounted with GVA mounting media from Zymed Labs (San Francisco).

\section{RESULTS}

Sera from 74 patients with rapidly progressive or sudden onset hearing loss were evaluated for reactivity with guinea pig inner-ear antigens using either Western blot ( 73 patients) or immunofluorescence ( 36 patients). The breakdown of the patients by type of hearing loss is shown in TABLE 1. Fifty-four patients had rapidly progressive hearing loss. Thirty-six of these had bilateral involvement, and 18 had unilateral involvement. Twenty patients had sudden hearing loss; of these, only two had bilateral effects. Of the 54 patients with rapidly progressive hearing loss, tested by Western blot, $28(52 \%)$ stained a $68-70-\mathrm{kD}$ protein. Similarly, one half of the of the sudden hearing loss patients $9 / 19(47 \%)$ were positive. Of the patients with rapidly progressive hearing loss $50 \%(18 / 36)$ with bilateral involvement and a slightly higher proportion, $56 \%(10 / 18)$, of the patients with unilateral involvement were Western blot positive. Examples of the Western blots are shown in FIGURE 1.

To determine the location of the inner-ear antigen, we tested Western blot positive sera, negative sera, normal donor sera, and a sera from a few previously untested patients by immunofluorescence on surface preparations of guinea pig organ of Corti.

TABLE 1. Serological Results by Type of Hearing Loss

\begin{tabular}{lccc}
\hline & \multicolumn{2}{c}{ Type of Hearing loss } & \\
\cline { 2 - 3 } & Rapidly Progressive & Sudden & Total \\
\hline Number of patients & 54 & 20 & 74 \\
Western blot & & & \\
$\quad$ Number positive/number tested & $28 / 54$ & $9 / 19$ & $37 / 73$ \\
$\quad \begin{array}{l}\text { Percent positive } \\
\text { Immunofluorescence }\end{array}$ & $(52 \%)$ & $(47 \%)$ & $(51 \%)$ \\
$\quad$ Number positive/number tested & $24 / 28$ & & \\
$\quad$ Percent positive & $(86 \%)$ & $(100 \%)$ & $(89 \%)$ \\
\hline
\end{tabular}




\section{Western blots with sera from patients UM-HL-03, $-04,-05$, and -12}

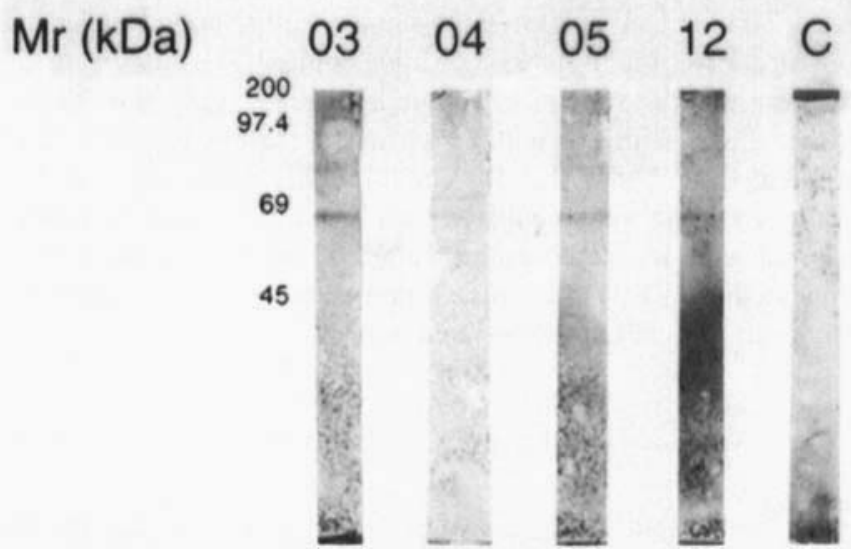

FIGURE 1. Western blot of human sera on guinea pig inner-ear extract. UM-HL indicates University of Michigan Hearing Loss patients 03 through 12. Lane $\mathbf{C}$ is serum from a normal donor.

Thus far, 32/36 (89\%) of the patients' sera stained supporting cells in the organ of Corti. The staining was distributed in punctate clusters over the surfaces of the supporting cells, including the surface of the pillar cells and the phalangeal processes of the Deiters' cells. Most Western blot positive sera, 29/31 (94\%), also were positive by IF (TABLE 2). Of the 36 cases that were tested by both assays, 29 sera were positive in both assays, three were negative in both, two were IF positive but Western blot negative, and two stained the $68-\mathrm{kD}$ protein on Western blot but did not stain supporting cells in the organ of Corti. Examples of supporting cell staining by seven-patient sera and one normal control serum are illustrated in FIGURE 2. This pattern was of particular interest to us because the patient sera replicated the staining pattern observed with the monoclonal antibody KHRI-3. ${ }^{20,22,24}$ Examples of staining by a patient's serum and the KHRI-3 antibody are compared in FIGURE 3.

TABLE 2. Results for Sera from Sudden and Rapidly Progressive Hearing-loss Patients Tested by Both Assays

\begin{tabular}{lcccc}
\hline & & \multicolumn{2}{c}{ Immunofluorescence } & \\
\cline { 3 - 4 } & & + & - & Total \\
\hline Western blot & + & 29 & 2 & 31 \\
& - & 2 & 3 & 5 \\
& Total & 31 & 5 & 36 \\
\hline
\end{tabular}



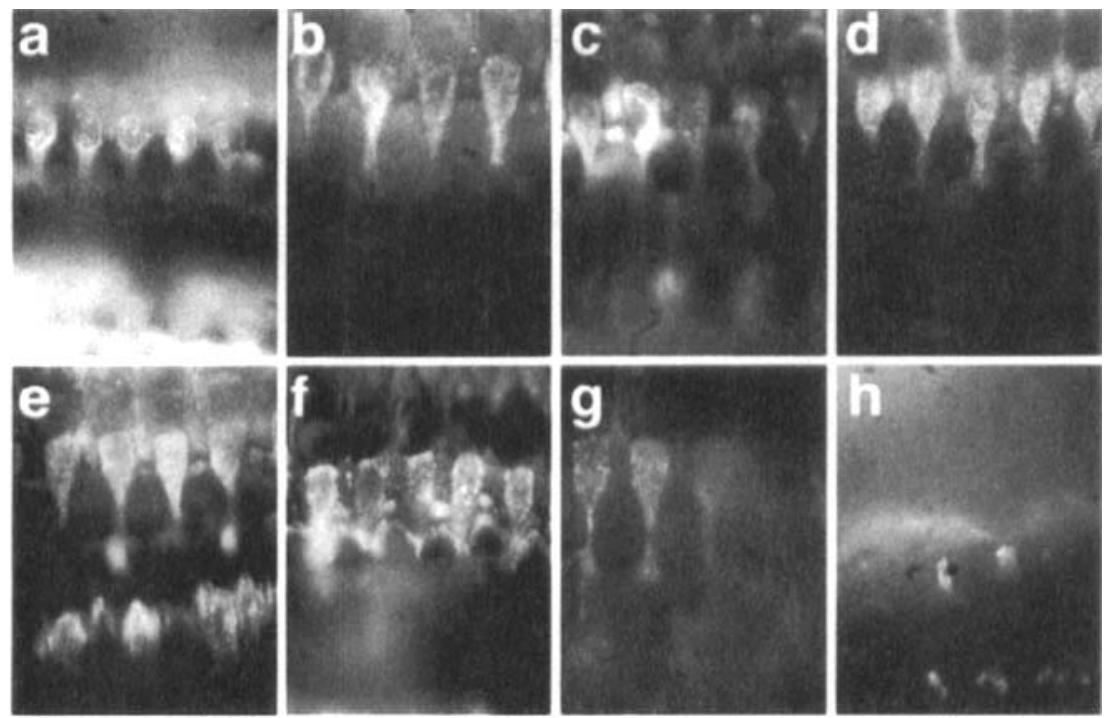

FIGURE 2. Immunofluorescence photomicrographs of surface preparations of guinea pig organ of Corti immunostained with human sera. Panels (a)-(g), sera from patients UM-HL-5, UM-HL-21, UM-HL-25, UM-HL-26, UM-HL-37, UM-HL-53, with sudden onset or rapidly progressive hearing loss; panel (h), serum from a normal donor. Note the punctate "wine glass" staining pattern of the supporting cells in each case incubated with the patients' sera. No such staining was observed with control sera, although the normal serum stained the stereocilia.

The similarity of staining and the prior observations that KHRI-3 can cause hearing loss ${ }^{20,24}$ suggested that the human sera might bind to the same antigen as KHRI3. To test this hypothesis, proteins precipitated from inner-ear extracts by KHRI-3 were subjected to SDS PAGE, Western blotted, and stained with patient sera. An example of this experiment is shown in FigURE 4. Thus far, $4 / 4$ patients' sera that were positive for the $68-70-\mathrm{kD}$ band by Western blot also stained a $70-\mathrm{kD}$ band in the ma-

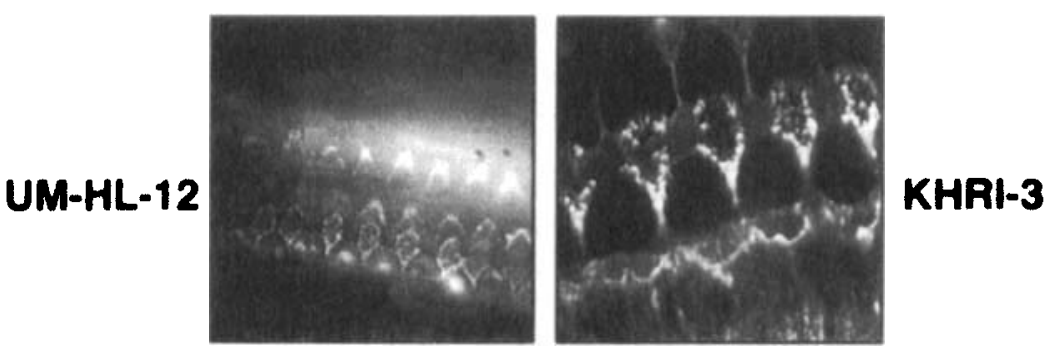

FIGURE 3. Confocal immunofluorescence photomicrographs of guinea pig organ of Corti surface preparations stained with serum from patient UM-HL-12 (left panel) and KHRI-3 monoclonal antibody (right panel). Note the similarity of the staining pattern on the supporting cells. 


\section{KHRI-3 Precipitates a 68 kDa Protein Identified by Human Autoantibody}

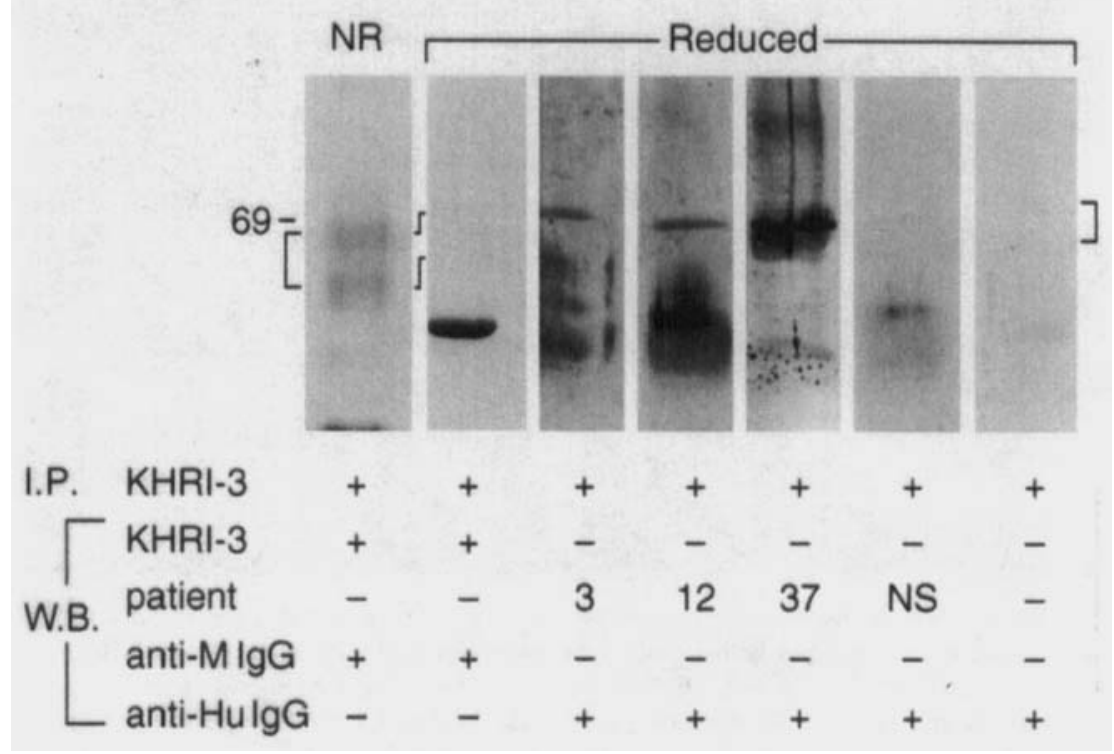

FIGURE 4. Immunoprecipitation and Western blot of guinea pig inner-ear tissue. Guinea pig inner-ear extracts were immunoprecipitated with the KHRI-3 mouse monoclonal antibody, and then the precipitated proteins were separated by electrophoresis under nonreducing conditions (NR, lane 1) or reducing conditions (reduced, lanes 2-7) and transferred to a nitrocellulose membrane. The left two lanes were then incubated with KHRI-3 antibody and developed with antimouse immunoglobulin. Lanes 3-6 were incubated with human sera from patients UMHL-03, -12 , and -37 , or with a normal serum sample and developed with antihuman immunoglobulin. Lane 7 is the second antibody control. Note that the autoimmune human sera stain a $68-70-\mathrm{kD}$ protein (bracket shows the region of the protein band) immunoprecipitated by KHRI-3 antibody. KHRI-3 antibody reacts best with nonreduced proteins, whereas the human sera react with the reduced proteins, indicating that the human sera bind to a different epitope than the murine antibody.

terial immunoprecipitated by KHRI-3. Normal sera controls were negative. The KHRI-3 antibody reacts best with nonreduced inner-ear proteins (FIG. 4, bracket on left). Under these conditions we can usually resolve a doublet of 65 and $67 \mathrm{kD}$. KHRI-3 reacts poorly with reduced proteins, but faint staining of the bands that shift to 68 and $70 \mathrm{kD}$ under reducing conditions can be discerned in lane 2 . The human sera appear to stain most strongly the upper band detected by KHRI-3 under reducing conditions (FIG. 4, bracket on right). The heavy band at $55 \mathrm{kD}$ in lane 2 is the reduced Ig heavy chain of the KHRI-3 antibody used to precipitate the inner-ear proteins. In contrast to KHRI-3, the human sera react best with reduced proteins, indicating that the human antibodies and the murine antibody may identify different conformational epitopes on the same protein. 


\section{Absorption of Autoantibody by Human Inner Ear Tissue}

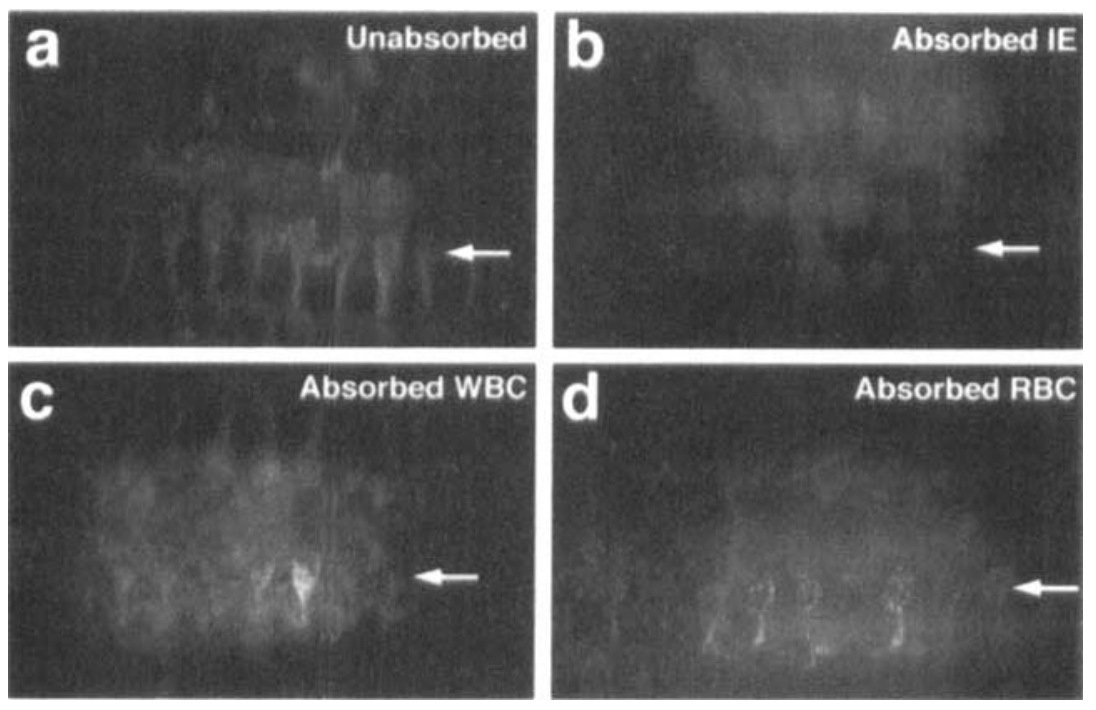

FIGURE 5. Immunofluorescence photomicrographs of guinea pig organ of Corti immunostained with an autoimmune hearing-loss serum showing the effects of absorption of the serum with: (a) no tissue; (b) human inner-ear tissue; (c) white blood cells from the inner-ear tissue donor; (d) red blood cells from the inner-ear tissue donor. Arrows indicate the location of the first row of supporting cells. Note that the staining of the supporting cells is eliminated after absorption with human inner ear, but not after absorption with blood cells from the same donor.

To determine if the antigen detected by patient sera in guinea pig inner-ear tissue is present in human inner ear, absorption analysis was performed. Inner-ear tissue removed from patients undergoing ablative inner-ear surgery was used as the source of inner-ear antigen, and white and red blood cells from the same donors were used as histocompatibility and blood group antigen controls. Equal volumes of either packed blood cells or inner-ear tissue were mixed with an aliquot of IF positive patient sera and then retested on guinea pig inner-ear substrate. As shown in FIGURE 5, absorption with inner ear but not blood cells removed the antibody reactivity to guinea pig inner ear. In a second experiment not shown, a similar but less complete absorption was obtained.

\section{DISCUSSION}

Although autoimmunity as one etiologic alternative for $\mathrm{SNHL}^{1,2}$ has not been conclusively confirmed, there is mounting evidence to suggest that it is one of the causes of SNHL in patients who have rapidly progressive loss. Much of the experi- 
mental and clinical evidence has involved the use of bovine inner-ear antigens. ${ }^{7.15-18}$ We used inner-ear antigens from guinea pigs in an attempt to develop a more readily available and consistent source of antigen for study. ${ }^{22,23}$ In this study with human sera, the use of guinea pig tissue also allowed us to employ established immunohistochemistry techniques and a previously prepared monoclonal antibody. ${ }^{22}$ Using Western blots, we have been able to demonstrate that $51 \%$ of patients with sudden onset and/or rapidly progressive hearing loss have antibody that reacts strongly with guinea pig inner-ear antigens. Our findings are similar to the observations of other investigators. The highest frequency of positive cases is reported by Hughes et al. ${ }^{25}$ who found antibodies to a $68-\mathrm{kD}$ antigen in $86 \%$ of patients. Moscicki et al. ${ }^{15}$ found that $58 \%$ of the 72 patients they tested with bilateral rapidly progressive hearing loss had antibody to a $68-72-\mathrm{kD}$ protein in bovine inner-ear extracts. Likewise, Harris and Ryan ${ }^{16}$ reported $32 \%$ of their large series of presumptive autoimmune hearing-loss cases were positive for antibody to a $68-\mathrm{kD}$ protein in bovine inner-ear extract. Veldman et al. ${ }^{28}$ found $65-73 \%$ of patients with sudden onset or rapidly progressing hearing loss, respectively, had antibody to multiple bands in Western blots including 27 , 45,50 , and $68 \mathrm{kD}$. Cao et al. ${ }^{19,21}$ used guinea pig inner-ear extracts similar to ours to detect human autoantibodies. These investigators did not observe a $68-70-\mathrm{kD}$ band; instead, they reported bands of 58 and $30 \mathrm{kD}$. We also noted that some patients sera stain multiple bands at 200,85 , and $55 \mathrm{kD}$, but for the purposes of this study we scored as positive only those sera staining a $68-70-\mathrm{kD}$ protein. The $68-70-\mathrm{kD}$ band was the most consistent and usually the most strongly stained band. As we reported previously, the inner-ear extracts are very sensitive to proteolytic breakdown.$^{23}$ If stringent extraction conditions using quick processing, rapid chilling on ice, and protease inhibitors are not used, then high molecular-weight bands may disappear and lower molecular-weight bands may appear in their place. However, Cao et al. ${ }^{19,21}$ used protease inhibitors, so the reasons for the absence of the $68-70-\mathrm{kD}$ protein in their results is not clear.

There have been a number of reports of human sera staining inner-ear tissue and human temporal bone specimens ${ }^{29}$ as summarized by Soliman. ${ }^{30}$ However, to our knowledge there have been no previous reports of consistent staining of the supporting cells in the organ of Corti such as we observed. This may be because many of the other investigators used cross sections rather than surface preparations. In cross section, supporting cell staining, unless it is very intense, ${ }^{22,31}$ is less apparent than it is when viewed from the surface. The "wine-glass" staining pattern we observed with the human autoimmune sera on the phalangeal processes of the outer pillar cells and Deiters' cells is like that which we previously reported with the KHRI-3 monoclonal antibody. ${ }^{20,22,24}$ Furthermore, there was a strong concordance between staining of the $68-\mathrm{kD}$ protein and the wine-glass staining pattern on organ of Corti supporting cells, since $>90 \%$ of sera that had antibody to the $68-\mathrm{kD}$ band also stained supporting cells. This is consistent with the notion that the $68-\mathrm{kD}$ protein is expressed on the supporting cells. Since the KHRI-3 antibody has been linked to hearing loss and damage to the organ of Corti in both mice ${ }^{20}$ and guinea pigs, ${ }^{24}$ we found this pattern of staining to be quite interesting. It suggested to us that the human autoantibodies might bind to the same protein as the KHRI-3 antibody and that both antibodies might have a common mechanism of inducing hearing loss. To further investigate this possibility, we immunoprecipitated inner-ear proteins using the KHRI-3 antibody and then tested if 
the human antibodies would stain those immunoprecipitated proteins. As shown in FIGURE 4, this is the case. Our results support the concept that the human antibodies detected with guinea pig inner-ear tissue could be pathogenic in humans. However, until now there has been no evidence that antigens detected by human sera in guinea pig or bovine inner ear are also expressed in the human inner ear. Our last experiment shown in this paper demonstrates that the antigen we detect in guinea pig inner ear using human sera is also expressed specifically in human inner-ear tissue. Human inner-ear tissue but not lymphocytes or red blood cells from two tissue donors was capable of absorbing the antibodies that bind to the guinea pig supporting cells. If the human inner ear did not contain the same antigen as the guinea pig inner ear, then the absorption would not have removed the antibody. This is compelling evidence that antibodies to inner-ear antigens that are present in the sera of a high proportion of sudden onset, rapidly progressive hearing loss patients do bind to human inner-ear antigens and may well have pathogenic effects themselves as suggested by their similarity to the pathogenic KHRI-3 antibody.

The nature of the target antigen of human autoimmune sera has been suggested to be heat shock protein, specifically HSP-70. ${ }^{17}$ We don't know if this is correct or not, but we strongly suspect that HSP-70 is not the target of KHRI-3, because when proteins are precipitated from inner-ear extracts by KHRI-3 and Western blotted, nothing in the immunoprecipitate reacts with anti-HSP-70 antibodies. Thus, if KHRI-3 and human autoantibodies define the same antigen, then it seems unlikely that HSP-70 is the primary target of the human antibodies that stain proteins precipitated by KHRI3. This is an area of investigation in our and other laboratories and requires more work before any conclusions can be drawn.

The findings of this study support the hypothesis that autoimmune sensorineural hearing loss occurs in humans, and that its presence can be established by laboratory testing in at least some patients. Such test results may correlate with therapeutic response. ${ }^{15}$ In light of the clinical importance of accurately and rapidly diagnosing treatable, potentially reversible causes of sensorineural hearing loss, and considering the complications associated with the use of cytotoxic medications and corticosteroids, there is clearly a need for a readily available test to diagnose this condition.

\section{SUMMARY}

Autoimmunity is thought to be one cause of sensorineural hearing loss (SNHL). Sera from patients with rapidly progressive hearing loss have been shown to contain antibodies to a $68-\mathrm{kD}$ protein in heterologous inner-ear tissue. Using guinea pig inner-ear tissue as the antigenic substrate and either Western blot or immunofluorescence (IF) or both, we tested sera from 74 patients suspected to have autoimmune hearing loss for inner-ear antibodies. Sera from 73 patients were tested by Western blot, and sera from 36 were tested by IF. Thirty-seven of $73(51 \%)$ had antibody to a $68-70-\mathrm{kD}$ protein by Western blot. Sera positive by IF stained supporting cells with a staining pattern like that previously observed with the KHRI-3 monoclonal antibody. There was concordance between Western blot and IF assays. Of 36 patients tested by both assays, $29 / 31(94 \%)$ that were positive in Western blot were also positive by IF, three were negative by both tests, and two each were positive by one assay but nega- 
tive by the other. Absorption of patient sera with human inner-ear tissue removed antibody reactivity to the guinea pig supporting cells, indicating that the antigen detected by the autoantibody is also present in the human inner ear. Absorption with an equal volume of white or red blood cells from the tissue donor did not remove the antibody reactivity to inner ear, showing that the absorption by inner-ear tissue is specific. Sera from three patients positive in both assays also stained a $68-70-\mathrm{kD}$ innerear protein immunoprecipitated by the KHRI-3 monoclonal antibody, indicating that the monoclonal and human antibodies recognize the same antigen. The results support the hypothesis that patients with autoimmune sensorineural hearing loss produce autoantibodies to an inner-ear supporting cell antigen that is phylogenetically conserved and defined by the murine monoclonal antibody KHRI-3. Since KHRI-3 can induce hearing loss after infusion into the inner ear, it is likely that autoantibodies with the same antigenic target are also pathogenic in humans.

\section{REFERENCES}

1. LehnhardT, E. 1958. Plotzliche Horstorungen, auf beiden Selten gleichzeitig oder nacheinander aufgetreten. Z. Laryngol. Rhinol. Otol. 37: 1.

2. McCABE, B. F. 1979. Autoimmune sensorineural hearing loss. Ann. Otol. 88: 585-859.

3. Yoo, T. J., J. M. Stuart, A. H. Kang, A. S. Townes, K. Tomoda \& S. Dixit. 1982. Type II collagen autoimmunity in otosclerosis and Meniere's disease. Science 217: 1153-1155.

4. HARRIS, J. P. 1983. Immunology of the inner ear: Response of the inner ear to antigen challenge. Otolaryngol. Head Neck Surg. 91: 18-23.

5. Yoo, T. J., R. A. Floyd, N. Sudo, T. Ishibe, T. Takeda, K. Tomoda, Y. Yazawa, J. Stuart, I. S. CHOE \& S. C. HA. 1983. Factors influencing collagen-induced autoimmune ear disease. Am. J. Otolaryngol. 6: 209-216.

6. HARRIS, J. P. 1987. Experimental autoimmune sensorineural hearing loss. Laryngoscope 97: $63-76$.

7. HARRIS, J. P. \& P. A. SHARP. 1990. Inner ear autoantibodies in patients with rapidly progressive sensorineural hearing loss. Laryngoscope 100: 516-524.

8. Orozco, C. R., J. K. Niparko, B. C. Richardson, D. F. Dolan, M. U. Ptok \& R. A. ALTSCHULER. 1990. Experimental model of immune-mediated hearing loss using crossspecies immunization. Laryngoscope 100: 941-947.

9. Cruz, O. L. M., A. Miniti, W. Cossermelli \& R. M. Oliveira. 1990. Autoimmune sensorineural hearing loss: A preliminary experimental study. Am. J. Otol. 11: 342-346.

10. McCABE, B. F. 1991. Autoimmune inner ear disease: Results of therapy. Adv. Otorhinolaryngol. 46: 78-81.

11. Kusakari, C., K. Hozawa, S. Kolke, M. Kyoguku \& T. Takasaka. 1992. MLR/MPlpr/lpr mouse as a model of immune-induced sensorineural hearing loss. Ann. Otol. Rhinol. Laryngol. 101: 82-86.

12. TAGO, C. \& N. YANGITA. 1992. Cochlear and renal pathology in the autoimmune strain mouse. Ann. Otol. Rhinol. Laryngol. 157(Suppl.): 87-91.

13. Wong, M. L., J. S. Young, G. Nilaver, J. I. Morton \& D. R. Trune. 1992. Cochlear IgG in the $\mathrm{C} 3 \mathrm{H} /$ lpr autoimmune strain mouse. Hear. Res. 59: 93-100.

14. Sone, M., H. Nariuchi, K. Salto \& N. Yanagita. 1994. A substrain of NZB mouse as an animal model of autoimmune inner ear disease. Hear. Res. 83: 26-36.

15. Moscicki, R. A., J. E. San Martin, C. H. Quintero, S. D. Rauch, J. B. Nadol \& K. B. BLOCH. 1994. Serum antibody to inner ear proteins in patients with progressive hearing loss: Correlation with disease activity and response to corticosteroid treatment. JAMA 272: 611-616. 
16. Harris, J. P. \& A. F. RYAN. 1995. Fundamental immune mechanisms of the brain and inner ear. Otolaryngol. Head Neck Surg. 112: 639-653.

17. Billings, P. B., E. M. Keithley \& J. P. Harris. 1995. Evidence linking the 68 kilodalton antigen identified in progressive sensorineural hearing loss patient sera with heat shock protein 70. Ann. Otolol. Rhinol. Laryngol. 104: 181-188.

18. Gottschlich, S., P. B. Billings, E. M. Keithley, M. H. Weisman \& J. P. Harris. 1995. Assessment of serum antibodies in patients with rapidly progressive sensorineural hearing loss and Meniere's disease. Laryngoscope 105: 1347-1352.

19. Cao, M.-Y., M. Gersdorff, N. Deggouj, M. Warny \& J.-P. Tomasi. 1995. Detection of inner ear disease autoantibodies by immunoblotting. Mol. Cell Biochem. 146: 157-163.

20. Nair, T. S., Y. Raphael, D. F Dolan, T. J. Parrett, L. S. Perlman, V. R. Brahmbhatt, Y. Wang, X. Hou, G. Ghollzadeh, A. L. Nuttall, R. A. Altschuler \& T. E. Carey. 1995. Monoclonal antibody induced hearing loss. Hear. Res. 83: 101-113.

21. CAO, M. Y., N. Deggouj, M. GersdorfF \& J.-P. Toması. 1996. Guinea pig inner ear antigens: Extraction and application to the study of human autoimmune inner ear disease. Laryngoscope 106: 207-212.

22. Zajic, G., T. S. Nair, M. Ptok, C. Van Waes, R. A. Altschuler, J. Schacht \& T. E. CAREY. 1991. Monoclonal antibodies to inner ear antigens: I. Antigens expressed by supporting cells in guinea pig cochlea. Hear. Res. 52: 59-72.

23. Ptok, M., T. S. Nair, R. A. Altschuler, J. Schacht \& T. E. Carey, 1991. Monoclonal antibodies to inner ear antigens: II. Antigens expressed in sensory cell stereocilia. Hear. Res. 57: 79-90.

24. Nair, T. S., D. M. Prieskorn, J. M. Miller, A. Mori, J. Gray \& T. E. Carey. 1997. In vivo binding and hearing loss after intracochlear infusion of KHRI-3 antibody. Hear. Res. 107: $93-101$.

25. Hughes, G. B., R. Moscicki, B. P. Barna \& J. E. San Martin. 1994. Laboratory diagnosis of immune inner ear disease. Am. J. Otology. 15: 198-202.

26. LAEMMLI, U. K. 1970. Cleavage of structural proteins during the assembly of the head of bacteriophage T4. Nature 277: 680-685.

27. Towbin, H., T. Staehlin \& J. Gordon. 1979. Electrophoretic transfer of proteins from polyacrylamide gels to nitrocellulose sheets. Procedure and some applications. Proc. Natl. Acad. Sci. USA 73: 2599-2604.

28. Veldman, J. E., T. Hanada \& F. Meeuwsen. 1993. Diagnostic and therapeutic dilemmas in rapidly progressive sensorineural hearing loss and sudden hearing loss. A reappraisal of immune reactivity in inner ear disorders. Acta Otolaryngol. (Stockholm) 113: 303-306.

29. Arnold, W. \& C. R. Pfaltz. 1987. Critical evaluation of the immunofluorescence microscopic tests for identification of serum antibodies against human inner ear tissue. Acta Otolaryngol. (Stockholm) 103: 371-378.

30. Soliman, A. M. 1992. Immune mediated inner ear disease. Am. J. Otol. 13: 575-579.

31. Chen, H., I. Thalmann, J. C. Adams, K. B. Avraham, N. G. Copeland, N. A. Jenkins, D. R. Beier, D. P. Corey, R. Thalmann \& G. M. Duyk. 1995. cDNA cloning, tissue distribution, and chromosomal localization of Ocp2, a gene encoding a putative transcriptionassociated factor predominantly expressed in the auditory organs. Genomics 27: 389-398. 